\title{
Sediment concentration rating curves for a monsoonal climate: upper Blue Nile
}

\author{
Mamaru A. Moges ${ }^{1,2}$, Fasikaw A. Zemale ${ }^{1,2}$, Muluken L. Alemu ${ }^{1}$, Getaneh K. Ayele ${ }^{1}$, \\ Dessalegn C. Dagnew ${ }^{1}$, Seifu A. Tilahun ${ }^{2}$, and Tammo S. Steenhuis ${ }^{2,3}$ \\ ${ }^{1} \mathrm{PhD}$ Program in Integrated Water Management, Faculty of Civil and Water Resource Engineering, \\ Bahir Dar Institute of Technology, Bahir Dar University, Bahir Dar, Ethiopia \\ ${ }^{2}$ Faculty of Civil and Water Resource Engineering, Bahir Dar Institute of Technology, \\ Bahir Dar University, Bahir Dar, Ethiopia \\ ${ }^{3}$ Department of Biological and Environmental Engineering, Cornell University, Ithaca, NY 14853 USA
}

Correspondence to: Tammo S. Steenhuis (tss1@ cornell.edu)

Received: 17 October 2015 - Published in SOIL Discuss.: 21 December 2015

Revised: 24 April 2016 - Accepted: 10 May 2016 - Published: 21 July 2016

\begin{abstract}
Information on sediment concentration in rivers is important for design of reservoirs and for environmental applications. Because of the scarcity of continuous sediment data, methods have been developed to predict sediment loads based on few discontinuоus measurements. Traditionally, loads are being predicted using rating curves that relate sediment load to discharge. The relationship assumes inherently a unique relationship between concentration and discharge and therefore although performing satisfactorily in predicting loads, it may be less suitable for predicting concentration. This is especially true in the Blue Nile Basin of Ethiopia where concentrations decrease for a given discharge with the progression of the rainy monsoon phase. The objective of this paper is to improve the sediment concentration predictions throughout the monsoon period for the Ethiopian highlands with a modified rating type equation. To capture the observed sediment concentration pattern, we assume that the sediment concentration was at the transport limit early in the rainy season and then decreases linearly with effective rainfall towards source-limited concentration. The modified concentration rating curve was calibrated for the four main rivers in the Lake Tana basin where sediment concentrations affect fish production and tourism. Then the scalability of the rating type equation was checked in three 100 ha watersheds for which historic data were available. The results show that for predicting sediment concentrations, the (modified) concentration rating curve was more accurate than the (standard) load rating curve as expected. In addition loads were predicted more accurately for three of the four rivers. We expect that after more extensive testing over a wider geographical area, the proposed concentration rating curve will offer improved predictions of sediment concentrations in monsoonal climates.
\end{abstract}

\section{Introduction}

Only for a few rivers in the world and over a limited period, sediment concentrations have been measured at a daily or shorter frequency. In order to determine sediment loads in the absence of these measurements, models and rating curves have been used. Knowing the total sediment loads from rivers is essential for evaluating the siltation of reservoirs (Ali et al., 2014), assessment of soil erosion and nutrient loss (Walling, 1977). As a result knowledge of sedi- ment concentration is important in most environmental applications because among other things it hampers fish reproduction and reduces the esthetic value of surface waters (Vijverberg et al., 2012).

In the Blue Nile Basin, where the construction of the Grand Ethiopian Renaissance Dam is and planning of other hydroelectric dams are under way, determining sediment loads is becoming more urgent. At the same time concern for the environment has been increasing and it has been noted that the fish production in Lake Tana is decreasing due to 
increasing sediment concentrations (Vijverberg et al., 2012). Thus, the ability to predict accurately the sediment concentrations and loads to the lakes and man-made reservoirs has become important in the Ethiopian highlands where these are not available.

Modeling sediment loss is fraught with difficulties that unlike runoff is not bounded by the amount of rainfall. So there is no upper bound for sediment load in the absence of data. The models most commonly used for predicting soil loss are the Universal Soil Loss Equation (USLE) (Wischmeier and Smith, 1965) and its derivatives such as RUSLE (Revised Universal Soil Loss Equation) (Renard et al., 1991) and MUSLE (Modified Universal Soil Loss Equation) (Williams and Berndt, 1977) Hydrologic Engineering Center River Analysis System, (HEC-RAS; HEC, 1995), Water Erosion Prediction Technology (WEPP, Nearing et al., 1989), Agricultural Non-Point Source Pollution (AGNPS; Young et al., 1989), Erosion Productivity Calculator (EPIC; Jones et al., 1991), Soil and Water Assessment Tool (SWAT; Arnold et al., 1998) and Chemicals, Runoff and Erosion from Agricultural Environment Systems (CREAMS; Knisel, 1980). More sophisticated models used are the neural differential evolution (NDE), artificial adaptive neuro-fuzzy inference system (ANFIS), and artificial neural network (ANN) models (Masoumeh and Mehdi, 2012; Özgür, 2007). However, it is cumbersome to obtain the required data for these models especially in developing countries. The reason is that these models were originally developed for areas that have large amounts of data. For example, in the land use and land cover map, the leaf area index data that SWAT needs are not available. Similarly, the soil data in Ethiopia are very coarse and are missing basic information such as soil texture, hydraulic conductivity and other parameters that are difficult to measure in Ethiopia. Additional challenges using these models are the following: (i) the models have been developed in regions with a semi-arid temperate climate where the runoff mechanisms are governed by infiltration excess unlike the highland areas where saturation excess runoff is dominating (Steenhuis et al., 2009; Bayabil et al., 2010; Tilahun et al., 2013a, b, c) and (ii) almost all of the models need intensive data with many parameters that might be available centrally in developed countries but not in developing countries such as Ethiopia. Therefore, historically when concurrent concentration and discharge measurement were taken at irregular intervals, rating curves were often the preferred choice for predicting sediment loads (e.g., Walling, 1990) but also recently (e.g., Horowitz, 2010; Kokpinar et al., 2015; Choi and Lee, 2015; Kheirfam and Vafakhah, 2015). The abundance of papers on load rating curves in the refereed literature should not be surprising since the purpose of the measurements was to determine the amount of sediment that potentially could be deposited in rivers and reservoirs. In the literature, a limited number of articles developed sediment concentration rating curves. These few studies were carried out in Sweden (Fenn et al., 1985); Ontario, Canada (Irvine and Drake, 1987), British Columbia in Canada (Sichingabula, 1998), southern Australia (Sun et al., 2001) and for the Himalayan glacier in India (Arora et al., 2014). Thus, compared to the sediment load rating curves that are available throughout the world for many rivers, there are very few sediment concentration rating curves and none for a monsoon climate.

There is a connection between models and rating curves in sediment studies. Rating curves have been used to validate models. Previous simulations to predict sediment load in the Lake Tana basin such as Easton et al. (2010) and Setegn et al. (2009), used sediment load rating curves to generate the observed sediment load data for calibrating and validating the sediment load models. Developing better rating curves will result in better predictions generated from observed flows.

There are at least 20 different ways to convert the measured concentration and discharge data to a rating curve (Phillips et al., 1999: Horowitz, 2010). The most often used is a power function (Eq. 1) that relates sediment load (product of discharge and concentration) to discharge (Miller, 1951; Muller and Foerstner, 1968; Phillips et al., 1999; Masoumeh and Mehdi, 2012).

$M=a_{l} Q^{b}$,

where $M$ is the sediment load, $Q$ is the discharge and $a_{1}$ and $b$ are rating curve parameters determined by regression analysis using observed data (Gao, 2008).

The concentration, $C$, can be found by dividing the load (Eq. 1) with the discharge $Q$,

$C=a_{c} Q^{b-1}, \quad a_{c}=a_{l}$.

The load rating curve Eq. (1) inherently assumes a unique relationship between discharge and concentration (i.e., $a_{\mathrm{c}}$ is constant; Gao, 2008). However when observed sediment concentrations are plotted against discharge, there is usually significant scatter around the curve (Asselman, 2000; Gao, 2008; Walling, 1977) indicating that other factors in addition to discharge influence sediment concentrations. To compensate for variations, various modifications have been applied; these include dividing the sediment discharge data into seasonal or hydrologic groupings, applying various correction factors, or using non-linear regression equations (Horowitz, 2010; Phillips et al., 1999). In the Ethiopian highlands the scatter in the plot of discharge and sediment concentration is caused by the fact that the observed sediment concentrations in streams and rivers are decreasing for the same discharge with the progression of the rainy phase as shown by Guzman et al. (2013) and Tilahun et al. (2013c). The same pattern has also been observed in Tibet in the upper reaches of watersheds by Henck et al. (2010).

Various reasons are given for the decrease in concentration with the progression of the rainy phase: Tilahun et al. (2013b) pose that with the progression of the rainy phase of the monsoon the value of $a_{c}$ which is a function of the portion of 
newly plowed land takes the highest value in the beginning of the rainy season. This is due to unconsolidated soil rills form and the soil removed is transported by runoff. Nyssen et al. (2004), Vanmaercke et al. (2010), and Asselman (1999) showed that the sediment concentration depends on the sediment available for transport by runoff. Haile et al. (2006) and Awulachew et al. (2009) relate sediment concentration to the amount of plant cover protection which is increasing towards the end of the rainy period. However, Tebebu et al. (2010) noted that plant cover and sediment concentration were not statistically related. Zumr et al. (2015) noted that sediment transport originated from saturation excess interflow from sloping agricultural fields and was not related to plant cover. Zegeye et al. (2010) and Tilahun et al. (2013c) attributed the decreased loading with the cessation of the rill formations. In addition, the base flow increases at the end of rainy phase and dilutes the sediment concentrations.

Since the traditional method of determining rating curves for sediment loads assumes that the sediment concentrations are a unique function of the discharge, this method cannot be used in environmental applications for predicting sediment concentrations when the sediment concentration decreases throughout the season for a given amount of discharge. The objective of this paper is, therefore, to develop a realistic method in determining the decreasing sediment concentration with the progression of the monsoon using the limited data common in most of the tropics. The study is carried out in the Ethiopian highlands. Two groups of watershed sizes were selected to test how well the concentration rating curve performed. These consisted of four major rivers and their watersheds in the Lake Tana basin and three small wellmonitored 100 ha watersheds in another part of the Blue Nile basin.

\section{Theory: concentration rating curves}

To include the observed decreasing sediment concentration with the progression of the rainy season in predicting sediment concentrations, Steenhuis et al. (2009) and Tilahun et al. $(2013 \mathrm{~b}, \mathrm{c})$ adapted the theory originally developed by Hairsine and Rose (1992). This relationship as depicted in Fig. 1 is based on the assumption that the sediment load in the beginning of the rainy monsoon phase is at the transport limit when sediment is available from the plowed land and then linearly decreases with cumulative effective rainfall to a source-limited concentration. Source limiting describes the condition when the rate of detachment from the soil determines the sediment concentration. Transport limiting occurs when deposited and detached sediment are in equilibrium and the stream carries its maximum amount of sediment (Foster and Meyer, 1975). This is the case in the Ethiopian highlands when fields are plowed in the beginning of the rainy monsoon phase. Once the rill network is fully developed and stable, the sediment concentration will be-

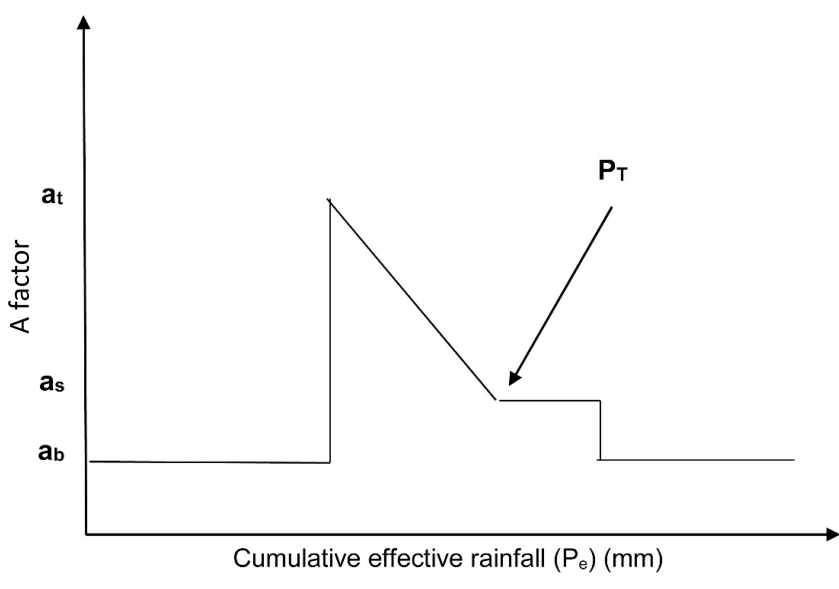

Figure 1. Relationship between sediment concentrations and cumulative effective rainfall.

come source limited (Tilahun et al., 2013b). Finally, as the surface runoff ceases and only base and interflow feeds the river, there will be small amounts of sediments that the water picks up from the riverbed or stirred up by animals or humans. Therefore, the sediment concentrations were calculated separately during the rainy monsoon phase and during the dry phase. Since the start of the rainy phase varies from year to year and from one location to another, we will use the cumulative effective rainfall, $P_{\mathrm{e}}$, to replace the "time" parameter. $P_{\mathrm{e}}$ is determined by summing the daily effective rainfall, which is equal to precipitation minus the potential evaporation for that day. The rainy phase starts when the cumulative effective rainfall, $P_{\mathrm{e}}$, is greater than $40 \mathrm{~mm}$ (from observation) and setting each time when $P_{\mathrm{e}}$ is negative to zero. As we will see later in most of the Lake Tana basin this occurs in the beginning of July, but it begins in mid-May in Gilgel Abay because the rainy phase starts earlier in a southern direction. For all of the watersheds the rainy phase ends at the beginning of October.

Based on these observations we redefine the " $\mathrm{a} c$ " in Eq. (2) for the rainy phase as

$$
\begin{array}{ll}
a_{c}=\left[a_{\mathrm{t}}+\left(a_{\mathrm{s}}-a_{\mathrm{t}}\right) \frac{P_{e}}{P_{\mathrm{T}}}\right] & \text { for } P_{\mathrm{e}}<P_{\mathrm{T}} \\
a_{c}=a_{\mathrm{s}} & \text { for } P_{\mathrm{e}} \geq P_{\mathrm{T}},
\end{array}
$$

where $a_{\mathrm{S}}$ is sediment source limiting factor, $a_{\mathrm{t}}$ is the sediment transport limiting factor, $P_{\mathrm{e}}$ is the cumulative effective rainfall $(\mathrm{mm})$ on a particular day, $P_{\mathrm{T}}$ is the threshold cumulative rainfall up to which amount the $a_{\mathrm{c}}$ parameter linearly decreases with cumulative rainfall, $P_{\mathrm{e}}$, and after which the sediment concentration remains at the source limit. Thus, when $P_{\mathrm{e}}$ is equal to or greater than $P_{\mathrm{T}}$, the ratio becomes one, which indicates that the sediment concentration is equal to the source limit. The " $a_{\mathrm{c}}$ " and " $a_{\mathrm{s}}$ " parameters depend on a number of factors such as slope length, particle size and disposability. In addition, " $a_{\mathrm{s}}$ " parameter varies with the cohesion of the soil (Yu et al., 1997). The threshold value was 
Table 1. Characteristics of the study watersheds in the Lake Tana Basin and the three 100 ha watersheds in the Ethiopian highlands.

\begin{tabular}{lllll}
\hline & Drainage area $\left(\mathrm{km}^{2}\right)$ & Mean annual rainfall (mm) & $\begin{array}{l}\text { Rating curve (Eq. 1) by MoWIE* } \\
\text { load rating Curve (RC) constants }\end{array}$ \\
\cline { 2 - 5 } Lake Tana watersheds & & & $a$ & $b$ \\
\hline Gilgel Abay & 1665 & 1912 & 4 & 1.65 \\
Ribb & 1288 & 1213 & 30 & 1.59 \\
Gumara & 1274 & 1540 & 17.5 & 1.48 \\
Megech & 500 & 1455 & 15.1 & 1.35 \\
100 ha watersheds & & & & \\
Debre Mawi & 0.91 & 1240 & - & - \\
Anjeni & 1.31 & 1658 & - & - \\
Maybar & 1.28 & 1320 & & \\
\hline
\end{tabular}

MoWIE*: Ministry of Water Irrigation Electricity.

found in other simulations to be around $600 \mathrm{~mm}$ (Tilahun et al., 2013a, b). The values of all three parameters are therefore difficult to predict a priori and need to be calibrated. As we will see hereafter they are in a relatively narrow range indicating that they have some physical meaning.

The value of the exponent $b$ in Eq. (1) can be set to 1.4 when there is a linear relationship between velocity and sediment concentration and the depth of water is small compared to its width (Ciesiolka et al., 1995; Yu et al., 1997; Tilahun et al., 2013a, b, c). Using this value for $b$ and combining Eqs. (2) and (3), the modified concentration rating curve can be written for the rainy phase as

$$
\begin{aligned}
& C=\left[a_{\mathrm{t}}+\left(a_{\mathrm{s}}-a_{\mathrm{t}}\right) \frac{P_{e}}{P_{\mathrm{T}}}\right] Q^{0.4} \text { for } P_{\mathrm{e}}<P_{\mathrm{T}} \\
& C=a_{\mathrm{s}} Q^{0.4} \text { for } P_{\mathrm{e}} \geq P_{\mathrm{T}} .
\end{aligned}
$$

For the dry monsoon phase the concentration is

$$
C=a_{\mathrm{b}} Q^{0.4} \text {. }
$$

The modified load rating curve can be obtained by multiplying Eq. (4) by $Q$. Then, for the rainy phase the load $M$ can be expressed as

$$
\begin{aligned}
& M=\left[a_{\mathrm{t}}+\left(a_{\mathrm{s}}-a_{\mathrm{t}}\right) \frac{P_{e}}{P_{\mathrm{T}}}\right] Q^{1.4} \text { for } P_{\mathrm{e}}<P_{\mathrm{T}} \\
& M=a_{\mathrm{s}} Q^{1.4} \text { for } P_{\mathrm{e}} \geq P_{\mathrm{T}} .
\end{aligned}
$$

And for the dry monsoon $M$ can be expressed as

$$
M=a_{\mathrm{b}} Q^{1.4} \text {. }
$$

\section{Materials and methods}

The load rating curve (Eqs. 1 and 2) and concentration rating curves (Eqs. 4 and 5) are evaluated for the rivers in the four major watersheds in the Lake Tana basin: Gilgel Abay, Gumara, Megech and Ribb. These are named, hereafter, as the
"Lake Tana watersheds". In addition, three small (approximately $100 \mathrm{ha}$ ) watersheds are selected for the assessment of scale effects in the concentration rating curve: Anjeni, Debre Mawi and Maybar. We will call these hereafter " 100 ha watersheds".

\subsection{Description of study areas}

The $15000 \mathrm{~km}^{2}$ Lake Tana basin is in the headwaters of the approximately $180000 \mathrm{~km}^{2}$ Blue Nile basin. The average annual discharge from Lake Tana is $3.8 \times 10^{9} \mathrm{~m}^{3}(3.8 \mathrm{BCM})$, which is approximately $7 \%$ of that of the Blue Nile at the Ethiopian-Sudanese border (Awulachew et al., 2009). The elevation in the basin ranges from 1787 to $4260 \mathrm{~m}$. The major rivers that contribute $93 \%$ of the inflow to the lake are Gilgel Abay, Ribb, Gumara and Megech. The gaging stations are located 95,20, 26 and $40 \mathrm{~km}$, respectively, to the lake inlet as shown in Fig. 2. The three micro-watersheds are Debre Mawi, Anjeni and Maybar. The 91ha Debre Mawi and the 113 ha Anjeni are located in the Blue Nile basin south of Bahir Dar at 35 and $220 \mathrm{~km}$ respectively. The 112 ha Maybar is just located on the boundary of the Blue Nile Basin near Dessie $300 \mathrm{~km}$ east of Bahir Dar. Average annual rainfall for all watersheds in this study varies from 1100 to over $1900 \mathrm{~mm} \mathrm{yr}^{-1}$ (Table 1).

\subsection{Available data}

\subsubsection{Discharge and sediment concentrations}

Irregularly measured discharge and sediment concentration data by Ministry of Water, Irrigation and Energy (MoWIE) for the major four rivers in Lake Tana basin were available from 1964 to 2008. The numbers of observations available for the Lake Tana watersheds used for this analysis period were 23, 53, 52, and 16 for the Gilgel Abay, Gumara, Ribb and Megech watersheds, respectively. The data of the 100 ha watersheds were collected for Anjeni and Maybar by ARARI (Amhara Region Agricultural Research Institute). The Debre 


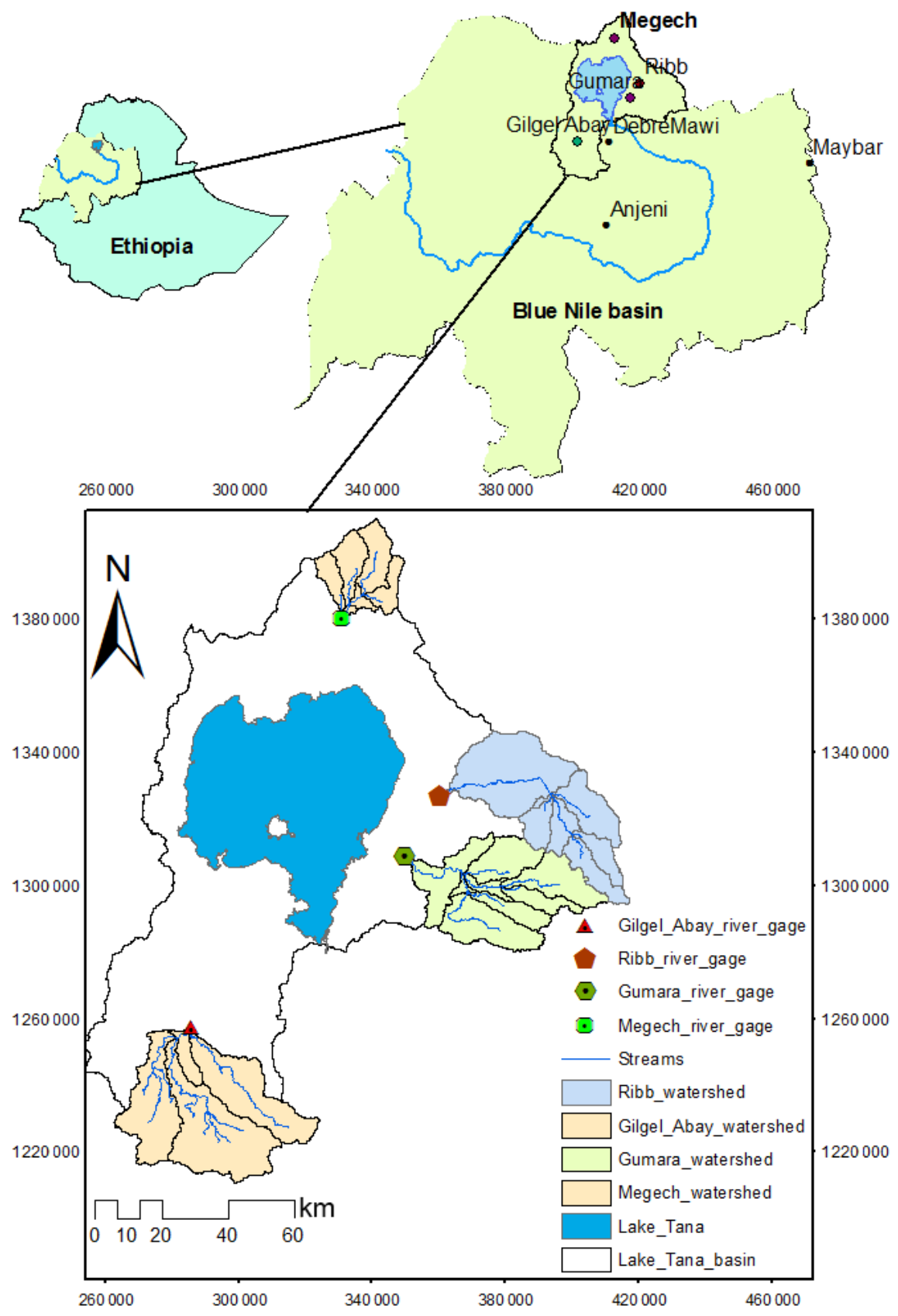

Figure 2. Location maps of the Lake Tana watersheds (Gilgel Abay, Gumara, Ribb and Megech) and 100 ha watershed 100 ha watersheds (Debre Mawi, Anjeni and Maybar) in or close to the Blue Nile Basin.

Mawi data were collected partly by ARARI and us and are described in Tilahun et al. (2013a, b).

The sediment concentrations in the Lake Tana watershed have been increasing since the initial measurements were made in 1964 (Ayana et al., 2014). We selected the following periods for analysis: 1968-2008 for Gilgel Abay, Gumara and Rib. The Megech data were only available and the analysis was made for 1990-2007. The analysis for the Anjeni was made for 1996 and for Anjeni in 1994 when the wa- tershed was stabilized from the soil and water conservation practices that were installed in the mid-1980s. For the Debre Mawi watershed the data in the years 2010 and 2011 were used before large-scale conservation practices were installed in 2012.

Climate data: rainfall and temperature data for the Lake Tana watersheds (Table 1) were available from 1994 to 2008 by the National Metrological Agency of Ethiopia (NMAE), Bahir Dar branch. The areal rainfall was calculated by using 
Table 2. The calibrated sediment rating curve parameters and the specific dates where the sediment transport ends and the sediment limiting phase starts.

\begin{tabular}{|c|c|c|c|c|c|}
\hline \multirow[t]{2}{*}{ River catchment } & \multicolumn{2}{|c|}{$\begin{array}{l}\text { A factor calibrated values } \\
\left(\mathrm{g}^{-1}\left(\mathrm{~mm} \mathrm{day}^{-1}\right)^{-0.4}\right.\end{array}$} & \multirow{2}{*}{$\begin{array}{l}\text { A factor for base flow }\left(a_{\mathrm{b}}\right) \\
\left(\mathrm{g}^{-1}\left(\mathrm{~mm} \mathrm{day}^{-1}\right)^{-0.4}\right. \\
a_{\mathrm{b}}\end{array}$} & \multirow{2}{*}{$\begin{array}{l}\text { Threshold effective } \\
\text { precipitation }(\mathrm{mm}) \\
P_{\mathrm{T}}\end{array}$} & \multirow[t]{2}{*}{$\begin{array}{l}\text { The date when } \\
\text { the } a_{\mathrm{s}} \text { starts }\end{array}$} \\
\hline & $a_{\mathrm{t}}$ & $a_{\mathrm{S}}$ & & & \\
\hline Gilgel Abay & 1.6 & 0.8 & 0.6 & 561 & 15 May \\
\hline Gumara & 5.9 & 1.5 & 0.7 & 574 & 15 Jun \\
\hline Ribb & 5.0 & 0.7 & 0.2 & 581 & 29 May \\
\hline Megech & 2.3 & 0.3 & 0.2 & 588 & 14 May \\
\hline Maybar & 5.1 & 0.7 & - & 598 & 15 May \\
\hline Debre Mawi & 6.9 & 1.1 & - & 599 & 5 Jun \\
\hline Anjeni & 3.1 & 1.8 & - & 596 & 27 May \\
\hline
\end{tabular}

Thiessen-polygon method for the available rainfall stations for the Lake Tana watersheds as these watersheds have two or more rainfall stations. The method was chosen because it is simple and does not require additional information. Details are given in the Supplement (Table S1). The Anjeni and Maybar precipitation and temperature measured in the watershed were made available by ARARI. The precipitation data for Debre Mawi were collected by us on site. To fill the missing data the gage at Adet ( $8 \mathrm{~km}$ away) was used. Temperature was obtained for the Adet station from the Adet Agricultural Research Center.

Potential evapotranspiration was estimated based on observed temperature data with the method developed by Enku and Melesse (2014).

Effective precipitation was calculated by subtracting the evaporation from rainfall each day. Cumulative effective precipitation was calculated during the rainy phase of the monsoon.

\subsection{Methods}

Rating curves were determined by either fitting the loads (i.e., the load rating curve) or the concentrations (concentration rating curve). Note that both the load and concentration rating curves can predict both the load and the concentration and thus the naming is based on the method of determining the rating curve.

The sediment load rating curve: the original MoWIE load rating curve was obtained for the Lake Tana watersheds by linearly regressing the logarithm of the sediment load vs. the logarithm of the discharge for the period from 1964 to 2008. The slope of the line is $b$ in Eq. (1) and the intercept gives the value of $a_{1}$. These are listed in Table 1. In addition, we followed the same procedure to determine the rating curve for the 100 ha watersheds. Sediment concentrations were determined by dividing the load with the corresponding discharge.

The concentration rating curve: rating curve was found by regressing the observed sediment concentrations and the discharge with Eq. (4). Four fitting parameters were required: three for the rainy phase, i.e., the amount of rainfall $P_{\mathrm{T}}$ after which the sediment is at the source limit and the source limiting factor $a_{\mathrm{s}}$ and a transport limiting factor $a_{\mathrm{t}}$. For the dry phase the parameter, $a_{\mathrm{b}}$, was required for the concentration in the base flow.

For the Lake Tana watersheds, precipitation and evaporation were only available for 1992-2000. In order to establish a $P_{T}$ value for the entire period for which discharge and sediment data were observed, average cumulative effective precipitation for the years from 1992 to 2000 as a function of the day was calculated for each watershed. For the 100 ha watersheds the average daily sediment concentrations and discharge and total rainfall data were available for the same years and the actual values of cumulative effective precipitation were used. Initial values for calibrating parameters $\left(a_{\mathrm{t}}\right.$ and $\left.a_{\mathrm{s}}\right)$ were based on Tilahun (2013a, b) for Debre Mawi watershed. These initial values of $\left(a_{\mathrm{t}}, a_{\mathrm{s}}\right.$ and $\left.P_{\mathrm{T}}\right)$ together with $a_{\mathrm{b}}$ were changed systematically till the best "closeness" or "goodness-of-fit" was achieved between measured and predicted sediment concentrations. The loads were obtained simply by multiplying the predicted concentrations by the observed discharge.

\subsection{Statistical analysis}

We first tested for outliers and those either less than half or more than twice the expected discharge or concentrations were removed from further analysis. In none of the cases no more than $5 \%$ of the data points were discarded. The goodness of fit of the rating curves were determined with the correlation coefficient $\left(R^{2}\right)$ and the Nash-Sutcliff coefficient (NS). The goodness of fit for model performance was based on Moriasi et al. (2007), and rated as very good for NS $>0.75$; good, when NS values were between 0.75 and 0.65 ; rated as satisfactory for values less than 0.65 but more than 0.5 and finally values less than 0.5 were considered poor. 
Table 3. Performance of sediment concentration predicted by MoWIE load rating curve and the concentration rating curve.

\begin{tabular}{lllll}
\hline \multirow{2}{*}{ River/watershed } & \multicolumn{2}{l}{ MoWIE load rating curve } & \multicolumn{2}{l}{ Concentration rating curve } \\
\cline { 2 - 5 } & NS & $R^{2}$ & NS & $R^{2}$ \\
\hline Gilgel Abay & 0.43 & 0.46 & 0.60 & 0.54 \\
Gumara & -0.022 & 0.17 & 0.61 & 0.60 \\
Ribb & -0.34 & -0.22 & 0.52 & 0.73 \\
Megech & 0.035 & 0.07 & 0.52 & 0.56 \\
Debre Mawi & - & - & 0.69 & 0.60 \\
Anjeni & - & - & 0.63 & 0.63 \\
Maybar & - & - & 0.68 & 0.63 \\
\hline
\end{tabular}

Table 4. Performance measures of sediment load predicted by MoWIE load rating curve and the concentration rating curve.

\begin{tabular}{lllll}
\hline \multirow{2}{*}{ River/watershed } & \multicolumn{2}{c}{ MoWIE load rating curve } & \multicolumn{2}{l}{ Concentration rating curve } \\
\cline { 2 - 5 } & NS* & $R^{2}$ & NS & $R^{2}$ \\
\hline Gilgel Abay & 0.60 & 0.66 & 0.61 & 0.64 \\
Gumara & 0.21 & 0.20 & 0.65 & 0.69 \\
Ribb & 0.54 & 0.61 & 0.61 & 0.67 \\
Megech & 0.78 & 0.84 & 0.83 & 0.89 \\
\hline
\end{tabular}

NS* : Nash-Sutcliffe efficiency.

\section{Results}

\subsection{Lake Tana watershed}

\subsubsection{Observed sediment concentration and load}

The available sediment concentration data for the Lake Tana watersheds calculated from the sediment load of the Ministry of Water Irrigation and Electricity (MoWIE) are shown in Fig. 3. There were three periods when samples were taken for determining the rating curve. These were from 1964 to 1968 , 1980 to 1996 and 2004 to 2008 (Fig. 3a and Tables S2-S5 in the Supplement). Gumara and the Ribb have the richest data set and the Gilgel Abay with only 23 data pairs is the poorest. Gumara and Ribb have also the greatest concentrations (Fig. 3). The concentration from the Megech is the smallest likely due to the Angereb man-made reservoir (which provides water supply for Gonder town) which was constructed in the early 1980s.

When these concentrations are plotted as a function of the day of the year independent of the year (Fig. 3b), the familiar pattern appears with the concentrations usually small in the base flow period from early October to the start of the rainy phase when concentrations increase. The elevated concentrations start around 15 May in the Gilgel Abay watershed, which is earlier than the other watersheds because the rain starts earlier in this part of the watershed. The concentrations in the other watersheds start to increase in late June (Table 2) and beginning of July. The maximum concentration occurs in late June and early July (Fig. 3b) while the discharge is still relatively small (Fig. 3c) and decreases with progression of the rainy phase while discharge is elevated.

\subsubsection{Evaluation of sediment concentration predictions}

The relationship between the observed vs. predicted sediment concentration for the Lake Tana watersheds is presented in Fig. 4 and the fitting statistics in Table 3. Both the concentration and sediment rating curves are used for obtaining the predicted sediment concentrations. Note that the concentration sediment rating curve refers to Eqs. (4) and (5) and involves four fitting parameters. Best fit values are shown in Table 2. The concentrations with the load rating curve are obtained by fitting the loads first and then obtaining the concentrations by dividing the load by the discharge. Here we use the values obtained by MoWIE load rating curve in Table 1.

For the Lake Tana watersheds, the sediment concentrations are under predicted by the MoWIE load rating curve and indicated poor prediction performance (Table 3, Fig. 4). The concentration rating curve fits the concentrations satisfactorily with Nash-Sutcliff values of 0.52 to 0.61 and $R^{2}$ values of 0.46 to 0.73 with slopes close to one (Table 3 , Fig. 4 ). The MoWIE load rating curves are poor in predicting concentrations.

\subsubsection{Evaluation of sediment load predictions}

Using the same rating curve parameters as in the concentration predictions above, the observed vs. predicted sediment 

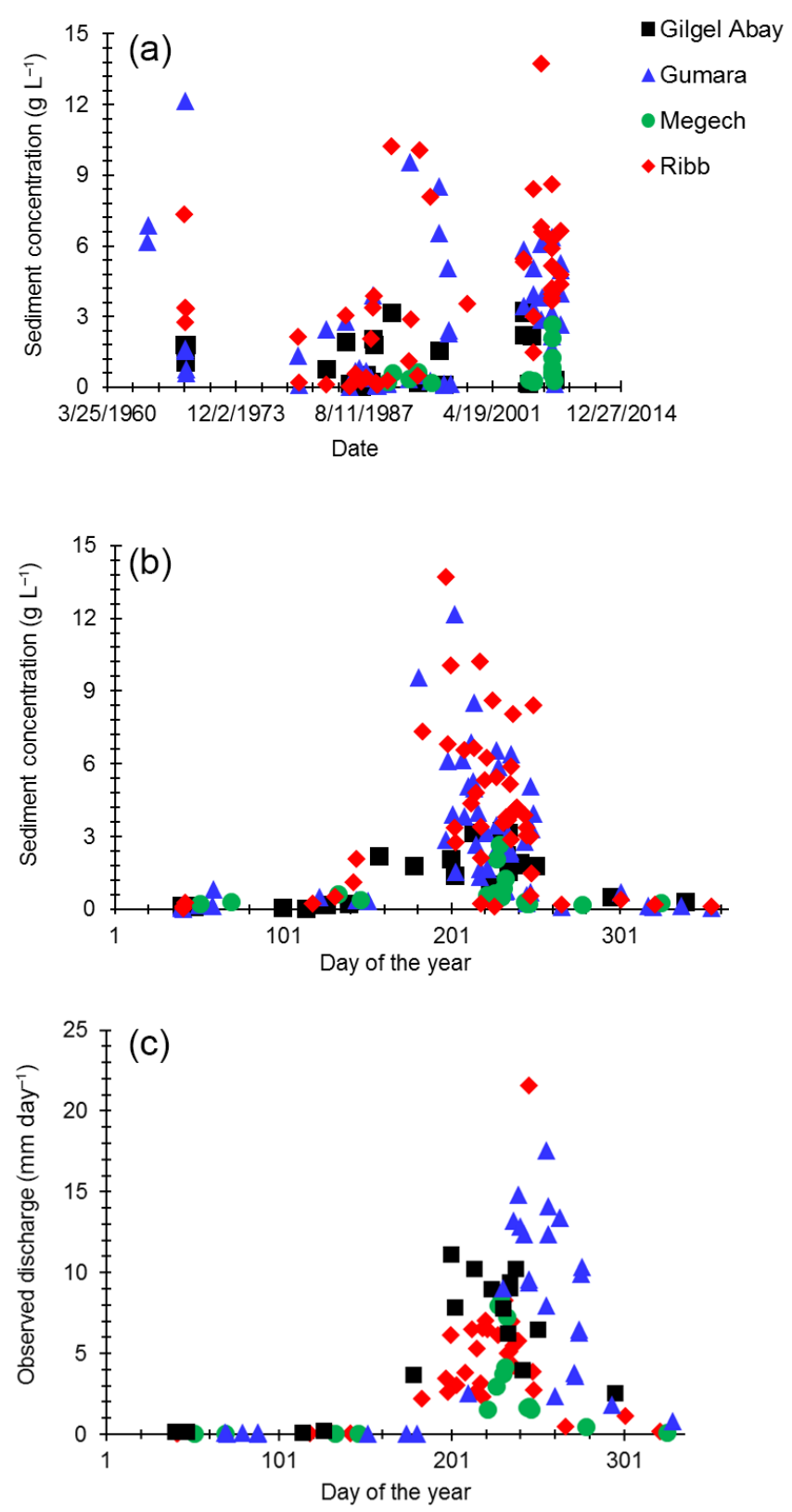

Figure 3. Observed sediment concentration and discharge for the four Lake Tana watersheds: Gilgel Abay, Gumara, Megech and Ribb. (a) Sediment concentration vs. date of sampling, (b) sediment concentration as a function of day of sampling independent of the year, and (c) observed discharge plotted vs. sampling day.

loads for the Lake Tana watersheds are shown in Fig. 5 and the goodness of fit in Table 4. The sediment loads (Fig. 6) are predicted to be between satisfactory and good with both the MoWIE load and concentration rating curves for Gilgel Abay, Ribb and Megech with $R^{2}$ values ranging from 0.61 to 0.84 (Fig. 5). The MoWIE load rating curve predicted the sediment load poorly for Gumara watershed. Generally, for the Lake Tana watersheds the concentration rating curves predict the loads more accurately than the MoWIE load rating curves with $R^{2}$ of $0.64-0.89$ (Table 4 ) and slopes between 0.72 and 0.94 (Fig. 5).

\subsection{Results of the three 100 ha watersheds}

After testing the sediment concentration rating curves for the Lake Tana watersheds, we investigated the applicability of the concentration rating curve for small watersheds. The three watersheds selected had good quality data. The concentration rating curve using Eqs. (3) and (4) gave a reasonably good fit with the observed values (Fig. 6) with $R^{2}$ values ranging from 0.60 to 0.63 (Table 3 ) with values for the transport coefficients similar to the Lake Tana watersheds. The source-limiting factor for Anjeni was the greatest and was likely caused by large active gully with unconsolidated soil that could be picked up easily by the flowing water.

\section{Discussion}

We will first discuss the loads and concentration predictions in the Lake Tana basin with the two types of rating curves followed by a comparison of the sediment load and concentration prediction with the concentration rating curve for the 100 ha and Lake Tana watersheds.

\subsection{Predicting sediment concentrations (Lake Tana watersheds)}

Similar to the predictions of the loads, the concentration rating curve fitted the observed concentrations better than those predicted by the MoWIE load rating curve. In addition to the reasons given for the poor fit (i.e., number of fitting parameters and $\log -\log$ fit), the inherent assumption of a constant sediment concentration for the MoWIE rating curve was clearly problematic for fitting observed concentrations. In the Ethiopian highlands concentrations are far from constant and usually follow a typical pattern where the concentrations are elevated during the beginning of the rainy season and decrease with the progression of the rainy season (Fig. 3b) while the discharge increases (Fig. 3c). Again similar to the loads, the Gilgel Abay fitted reasonably well because the concentrations were reasonably the same during the rainy phase (Fig. 3b, black squares).

\subsection{Predicting sediment loads (Lake Tana watersheds)}

For the Lake Tana watersheds, the concentration rating curve (Eq. 4) fitted the observed sediment load more accurately than the MoWIE load rating curve (Eq. 1) as shown in Fig. 5. The only exception was the sediment load predictions for the Gilgel Abay (Fig. 5a) that was slightly better predicted by the MoWIE load curve than the concentration rating curves. One could expect that the concentration rating curve would perform better because it has four fitting parameters compared 

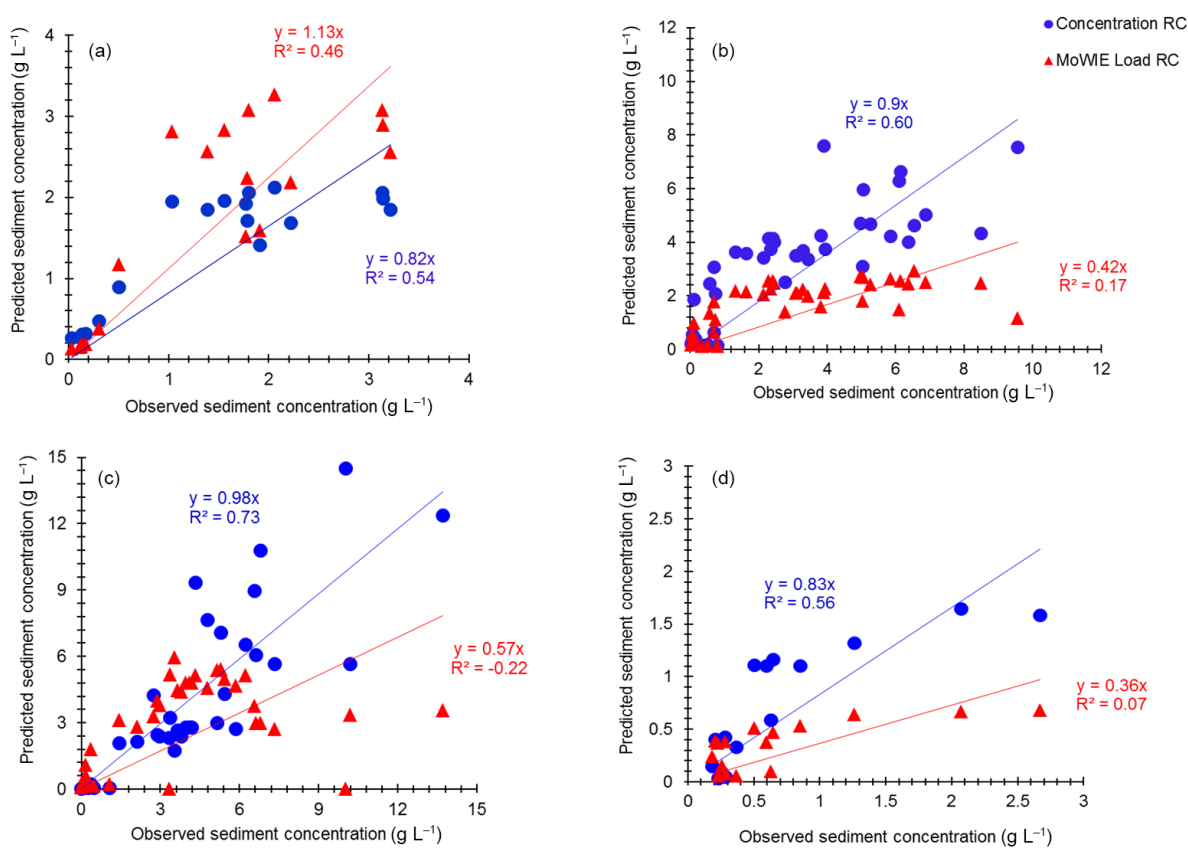

Figure 4. Predicted vs. observed sediment concentration using concentration rating curve and MoWIE load rating curve for the Lake Tana watersheds (a) Gilgel Abay, (b) Gumara, (c) Ribb, (d) Megech.
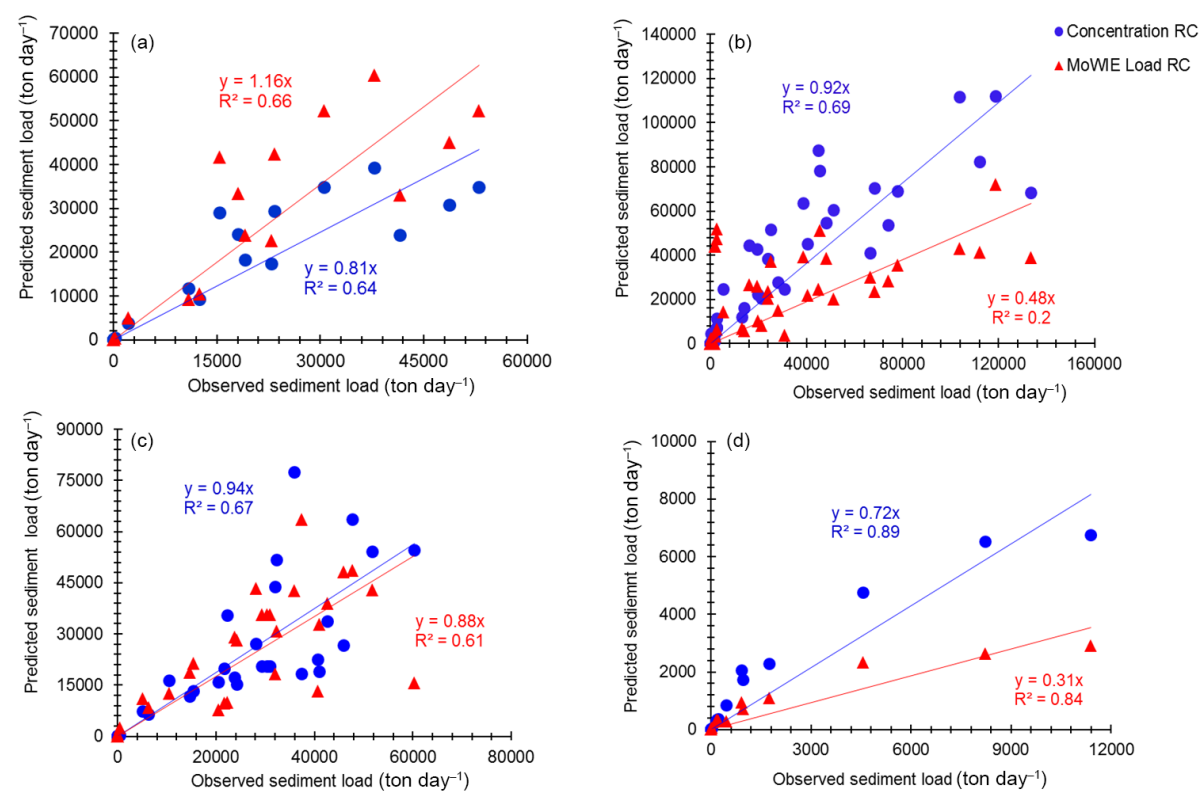

Figure 5. Predicted vs. observed sediment load using concentration rating curve and MoWIE load rating curve for the Lake Tana watersheds (a) Gilgel Abay, (b) Gumara, (c) Ribb, (d) Megech.

to the MoWIE sediment rating curve with only two parameters. In addition, there were few measurements taken early in the rain phase when sediment concentrations could have been elevated (Fig. 3).

However this does not explain the unexpected poor fit with slopes of much less than 1 for the remaining three watersheds in the Lake Tana basin (indicating that the sediment loads for the large storms are severely under predicted). This poor fit for the three watersheds originates from using the log-transformed values for fitting the sediment load and discharge. To demonstrate that the MoWIE log rating curve fits the $\log$ transformed values well we re-plotted Fig. 5a in the Supplement (Fig. S1) with a log scale. The log-transformed values give more weight to the small values of parameters 

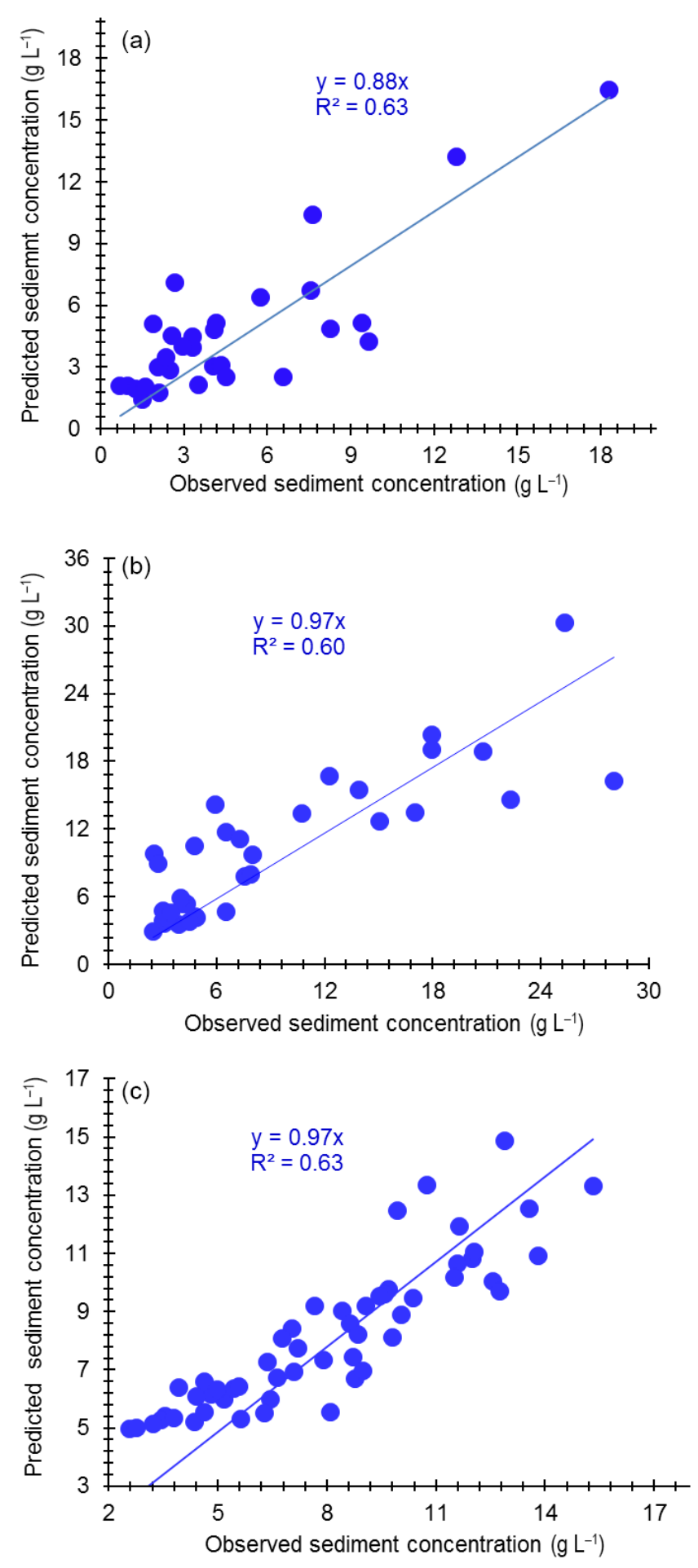

Figure 6. Predicted and observed sediment concentration using concentration rating curve for the 100 ha watersheds (a) Maybar, (b) Debre Mawi and (c) Anjeni.

than the larger values. Thus, by using the log scale a good fit was obtained, while the same points in the non-transformed values fit poorly (Fig. 5a).

\subsection{Concentration rating curve (100 ha and Lake Tana watersheds)}

All fitting parameters for the concentration rating curve were remarkable independent of the size of the watershed (Table 2). There was not a systemic difference in parameter values for the seven watersheds. The amount of effective rainfall $\left(P_{\mathrm{e}}\right)$ after which the concentration became independent of the rainfall (i.e., Eq. 5) varied between $561 \mathrm{~mm} \mathrm{yr}^{-1}$ for the Gilgel Abay and $599 \mathrm{~mm} \mathrm{yr}^{-1}$ for the Debre Mawi watershed. The difference among these values in all watersheds was not significant.

In further discussion of the sediment transport parameters we will exclude the Megech, since the gage station is located below the reservoir. Sediment is deposited in the reservoir and the parameters are not representative of the watershed that is subject to heavy gullying. For the remaining six watersheds, the source factor $a_{\mathrm{s}}$ varied from $0.7 \mathrm{~g} \mathrm{l}^{-1}$ $\left(\mathrm{mm} \mathrm{day}^{-1}\right)^{-0.4}$ for Maybar to $1.8 \mathrm{~g} \mathrm{l}^{-1}\left(\mathrm{~mm} \mathrm{day}^{-1}\right)^{-0.4}$ for Anjeni. The smaller values are related to watersheds with a minimum of gullying such as Maybar. The greater values are associated with watershed with active gullying such as Anjeni, Gumara and Debre Mawi (Table 2; Tilahun et al., 2015; Dagnew et al., 2015).

There was a 3-fold difference in transport coefficients (but independent of watershed area as indicated in Table 2). It varies in the Lake Tana basin between $1.6 \mathrm{~g} \mathrm{~L}^{-1}\left(\mathrm{~mm} \mathrm{day}^{-1}\right)^{-0.4}$ for the Gilgel Abay and $5.9 \mathrm{~g} \mathrm{~L}^{-1}$ $\left(m m \text { day }^{-1}\right)^{-0.4}$ for the Gumara. The basic assumption in the concentration rating curve is that the sediment concentrations are determined by the transport capacity after land is plowed and rills are formed. Differences in the value for the transport coefficient can be related to the slope of the watershed since the transport coefficients are dependent on the stream power and the stream power is a function of slope (Gao, 2008). The Gilgel Abay has $22 \%$ of land in the lowest slope category ( 0 $2 \%$ ), which is 3 times that in Ribb and Gumara. Moreover, the Gilgel Abay has only $1 \%$ in slope of greater than $30 \%$ while the other watershed has $9 \%$ or more in this category. Similarly in Anjeni, where most land is terraced and gently sloping, has a small transport limiting coefficient (a) compared to the Maybar and Debre Mawi watersheds that do not have terraces and have agricultural land with greater slopes. In both Gilgel Abay (Fig. 3b) and the Anjeni (not shown) watersheds, the concentrations in the beginning of the rainy phase are less pronounced than the other four watersheds. Thus, the low value of the transport coefficient is most likely related to the slope of the cultivated land in the watershed.

Finally the " $a_{\mathrm{b}}$ " values that determine the concentration during base flows are related to the stream channel erosion that in the case of the Gumara has the greatest value. This can be related to several factors, i.e., increasing population and activities for natural resource competition. This includes pumping water for irrigating cash crops during the dry mon- 
soon phase from the river. In addition, sand is being mined from the river bed.

\section{Conclusions}

In the Ethiopian highlands sediment concentrations in the rivers decrease with progression of the rainy phase of the monsoon. Using this observation while developing the sediment rating curve significantly improves for predicting the sediment concentration and load. The method developed by the Ministry of Water Irrigation and Energy and used for predicting daily loads throughout Ethiopia will likely remain the method of choice for most rivers especially for larger basins where concentrations remain relatively constant. Although more research has to be done, there is an indication that the coefficients in the newly developed concentration rating curve can be related to landscape characteristics. Therefore, these parameters might have a physical meaning which would help to generate the parameters from the physical $w a-$ tershed characteristics for the ungaged catchments for predicting concentrations and load in the upper Blue Nile Basin.

\section{The Supplement related to this article is available online at doi:10.5194/soil-2-337-2016-supplement.}

Acknowledgements. Funding for this program is provided by the US Agency for International Development (USAID) through PEER Science program and Higher Education for Development (HED), International Science Foundation (ISF). The runoff and sediment data were made available by Ministry of Water and Energy. We would like to thank MoWIE for making the rating curve data available to us.

Edited by: B. van Wesemael

\section{References}

Ali, Y. S. A., Crosato, A., Mohamed, Y. A., Abdalla, S. H., and Wright, N. G.: Sediment balances in the Blue Nile River Basin, Int. J. Sediment Res., 29, 316-328, 2014.

Arora, M., Kumar, R., Kumar, N., and Malhotra, J.: Assessment of suspended sediment concentration and load from a large Himalayan glacier, Hydrol. Res., 45, 292-306, 2014.

Arnold, J. G., Srinivasan, R., Muttiah, R. S., and Williams, J. R.: Large area hydrologic modeling and assessment part I: Model development, JAWRA, 34, 73-89, 1998.

Asselman, N. E. M.: Suspended sediment dynamics in a large basin: the River Rhine, Hydrol. Process., 13, 1437-1450, 1999.

Asselman, N. E. M.: Fitting and interpretation of sediment rating curves, J. Hydrol., 234, 228-248, 2000

Awulachew, S. B., Mccartney, M., Steenhuis, T. S., and Ahmed, A. A.: A review of hydrology, sediment and water resource use in the Blue Nile Basin, International Water Mangement Institute (IWMI), 131, 81 pp., 2009.

Ayana, E. K., Philpot, W., and Steenhuis, T. S.: Evaluating suitability of modis-terra images for reproducing historic sediment concentrations in water bodies: Lake Tana, Ethiopia International Journal of Applied Earth Observations and Geoinformation, 26, 286-297, 2014.

Bayabil, H. K., Tilahun, S. A., Collick, A. S., Yitaferu, B., and Steenhuis, T. S.: Are runoff processes ecologically or topographically driven in the (sub) humid Ethiopian highlands? The case of the Maybar watershed, Ecohydrology, 3, 457-466, 2010.

Choi, S. U. and Lee, J.: Assessment of total sediment load in rivers using lateral distribution method, J. Hydro Environ. Res., 9, 381387, doi:10.1016/j.jher.2014.06.002, 2015.

Ciesiolka, C. A., Coughlan, K. J., Rose, C. W., Escalante, M. C., Hashim, G. M., Paningbatan, E. P., and Sombatpanit, S.: Methodology for a multi-country study ofsoil erosion management, Soil Technol., 8, 179-192, 1995.

Dagnew, D. C., Guzman, C. D., Zegeye, A. D., Tibebu, T. Y., Getaneh, M., Abate, S., Zemale, F. A., Ayana, E. K., Tilahun, S. A., and Steenhuis, T. S.: Impact of conservation practices on runoff and soil loss in the sub-humid Ethiopian Highlands: The Debre Mawi watershed, J. Hydro. Hydromech., 63, 210-219, doi:10.1515/johh-2015-002, 2015.

Easton, Z. M., Fuka, D. R., White, E. D., Collick, A. S., Biruk, A. B., McCartney, M., Awulachew, S. B., Ahmed, A. A., and Steenhuis, T. S.: A multi basin SWAT model analysis of runoff and sedimentation in the Blue Nile, Ethiopia, Hydrol. Earth Syst. Sci., 14, 1827-1841, doi:10.5194/hess-14-1827-2010, 2010.

Enku, T. E. and Melesse, A. M.: A Simple Temperature Method for the Estimation of Evapotranspiration, Hydrol. Process., 28, 2945-2960, 2014.

Fenn, C. R., Gurnell, A. M., and Beecroft, I. R.: An Evaluation of the Use of Suspended Sediment Rating Curves for the Prediction of Suspended Sediment Concentration in a Proglacial Stream, Geogr. Ann. A, 67, 71-82, 1985.

Foster, G. and Meyer, L.: Mathematical simulation of upland erosion by fundamental erosion mechanics, Present and prospective technology for predicting sediment yields and sources, US Department of Agriculture, Washington, DC, 190-207, 1975.

Gao, P.: Understanding watershed suspended sediment transport, Progress in Physical Geography, 32, 243-264, 2008.

Guzman, C. D., Tilahun, S. A., Zegeye, A. D., and Steenhuis, T. S.: Suspended sediment concentration-discharge relationships in the (sub-) humid Ethiopian highlands, Hydrol. Earth Syst. Sci., 17, 1067-1077, doi:10.5194/hess-17-1067-2013, 2013.

Haile, M., Herweg, K., and Stillhardt, B.: Sustainable land management - a new approach to soil and water conservation in Ethiopia, Land Resource Management and Environmental Protection Department, Mekelle University, Mekelle, Ethiopia, Center for Development and Environment (CDE), University of Bern and Swiss National Center of Competence in Research (NCCR) North-South, Bern, Switzerland, 269 pp., 2006.

Hairsine, P. B. and Rose, C. W.: Modeling water erosion due to overland flow using Physical principles 1. Sheet flow, Water Resour. Res., 28, 237-243, 1992.

HEC (Hydrologic Engineering Center): Flow Transitions in Bridge Backwater Analysis, US Army Corps of Engineers, Davis, CA, pp.71, 1995 
Henck, A. C., Montgomery, D. R., Huntington, K. W., and Liang, C.: Monsoon control of effective discharge, Yunnan and Tibet, Geology, 38, 975-978, 2010.

Horowitz, A. J.: A quarter century of declining suspended sediment fluxes in the Mississippi River and the effect of the 1993 flood, Hydrol. Process., 24, 13-34, 2010.

Irvine, K. N. and Drake, J. J.,: Process-Oriented Estimation of Suspended Sediment Concentration, JAWRA, 23, 1017-1025, 1987.

Jones, C., Dyke, P., Williams, J., Kiniry, J., Benson, V., and Griggs, R.: EPIC: an operational model for evaluation of agricultural sustainability, Agr. Syst., 37, 341-350, 1991.

Kheirfam, H. and Vafakhah M.: Assessment of some homogeneous methods for the regional analysis of suspended sediment yield in the south and southeast of the Caspian Sea, J. Earth Syst. Sci., 124, 1247-1263, doi:10.1007/s12040-015-0604-7, 2015.

Knisel, W. G.: CREAMS. A field-scale model for chemicals, runoff and erosion from agricultural management systems, USDA Conservation Research Report, 640 pp. 1980.

Kokpinar, M. A., Altan-Sakarya, A. B., Kumcu, S. Y., and Gogus, M.: Assessment of sediment yield estimations for large watershed areas: a case study for the Seyhan, Demirkopru and Hirfanli reservoirs in Turkey, Hydrol. Sci. J., 60, 2189-2203, doi:10.1080/02626667.2014.959954, 2015.

Masoumeh, R. and Mehdi, F.: Estimating Suspended sediment concentration by a neural differential evolution (NDE) and comparison to ANFIS and three ANN Models, Disaster Adv., 5, 346-359, 2012

Miller, C. R.: Analysis of flow-duration, sediment-rating curve method of computing sediment yield, Denver, US Bureau of Reclamation, 55 pp., 1951.

Moriasi, D., Arnold, J., Van, L. M., Bingner, R., Harmel, R., and Veith, T.: Model evaluation guidelines for systematic quantification of accuracy in watershed simulations, T. Am. Soc. Agr. Biol. Eng., 50, 885-900, 2007.

Mueller, G. and Foerstner, U.: General relationship between suspended sediment Concentrations and water discharge in the Alpenrhein and some other rivers, Nature, 217, 244-245, 1968.

Nearing, M., Foster, G., Lane, L., and Finkner, S.: A process-based soil erosion model for USDA-Water Erosion Prediction Project technology, T. Am. Soc. Agr. Biol. Eng., 32, 1587-1593, 1989.

Nyssen, J., Poesen, J., Moeyersons, J., Deckers, J., Haile, M., and Lang, A.: Human impact on the environment in the Ethiopian and Eritrean Highlands - a state of the art, Earth Sci. Rev., 64, 273-320, 2004.

Özgůr, K.: Development of Stream flow-Suspended Sediment Rating Curve Using a range dependent neural network, Int. J. Sci. Technol., 2, 49-61, 2007.

Phillips, J. M., Webb, B. W., Walling, D. E., and Leeks, G. J. L.: Estimating the suspended sediment loads of rivers in the LOIS study area using infrequent samples, Hydrol. Process., 13, 10351050, 1999.

Renard, K. G., Foster, G. R., Wessies, D. K., and Yoder, D. C.: Prediction of soil erosion by water: A guide to conservation planning with the Revised Universal Soil Loss Equation (RUSLE), Report ARS 703, Agricultural Research Service, US Department of Agriculture, 1991.

Setegn, S. G., Srinivasan, R., Dargahi, B., and Melesse, A. M.: Spatial delineation of soil erosion vulnerability in the
Lake Tana Basin, Ethiopia, Hydrol. Process., 23, 3738-3750, doi:10.1002/hyp.7476, 2009.

Sichingabula, H. M.: Factors controlling variations in suspended sediment concentration for single-valued sediment rating curves, Fraser River, British Columbia, Canada, Hydrol. Process., 12, 1869-1894, 1998.

Steenhuis, T. S., Collick, A. S., Easton, Z. M., Leggesse, E. S., Bayabil, H. K., White, E. D., Awulachew, S. B., Adgo, E., and Ahmed, A. A.: Predicting Discharge and Erosion for the Abay (Blue Nile) with a simple model, Hydrol. Process., 23, 37283737, 2009.

Sun, H., Cornish, P. S., and Daniell, T. M.: Turbidity-based erosion estimation in a catchment in South Australia, J. Hydrol., 253, 227-238, doi:10.1016/S0022-1694(01)00475-9, 2001.

Tebebu, T. Y., Abiy, A. Z., Dahlke, H. E., Easton, Z. M., Zegeye, A. D., Tilahun, S. A., Collick, A. S., Kidnau, S., Moges, S., Dadgari, F., and Steenhuis, T. S.: Surface and subsurface flow effect on permanent gully formation and upland erosion near Lake Tana in the northern highlands of Ethiopia, Hydrol. Earth Syst. Sci., 14, 2207-2217, doi:10.5194/hess-14-2207-2010, 2010.

Tilahun, S. A., Mukundan, R., Demisse, B. A., Engda, T. A., Guzman, C. D., Tarakegn, B. C., Easton, Z. M., Collick, A. S., Zegeye, A. D., Schneiderman, E. M., Parlange J. Y., and Steenhuis, T. S.: A Saturation Excess Erosion Model, T. Am. Soc. Agr. Biol. Eng., 56, 681-695, 2013a.

Tilahun, S. A., Guzman, C. D., Zegeye, A. D., Ayana, E. K., Collick, A. S., Yitaferu, B., and Steenhuis, T. S.: Spatial and Temporal Patterns of Soil Erosion in the Semi-humid Ethiopian Highlands: A Case Study of Debre Mawi Watershed. In Nile River Basin: Ecohydrological Challenges, Climate Change and Hydropolitics, 149-163, edited by: Melesse, A. M., Abtew, W., and Setegn, G. S., Springer International Publishing Switzerland, 2013b.

Tilahun, S. A., Guzman, C. D., Zegeye, A. D., Engda, T. A., Collick, A. S., Rimmer, A., and Steenhuis, T. S.: An efficient semi-distributed hillslope erosion model for the subhumid Ethiopian Highlands, Hydrol. Earth Syst. Sci., 17, 1051-1063, doi:10.5194/hess-17-1051-2013, 2013c.

Tilahun, S. A., Guzman, C. D., Zegeye, A. D., Dagnew, D. C., Collick, A. S., Yitaferu, B., and Steenhuis, T. S.: Distributed discharge and sediment concentration predictions in the sub-humid Ethiopian highlands: the Debre Mawi watershed, Hydrol. Process., 29, 1817-1828, 2015.

Vanmaercke, M., Zenebe, A., Poesen, J., Nyssen, J., Vertstraeten, G., and Deckers, J.: Sediment dynamics and the role of flash floods in sediment export from medium-sized catchments: a case study from the semi-arid tropical highlands in northern Ethiopia, J. Soil Sed., 10, 611-627, 2010

Vijverberg, J., Dejen, E., Getahun, A., and Nagelkerke, L. A.: The composition of fish communities of nine Ethiopian lakes along a north-south gradient: threats and possible solutions, Anim. Biol., 62, 191 pp., 2012.

Walling, D. E.: Assessing the accuracy of suspended sediment rating curves for a small basin, Water Resour. Res., 13, 531-538, 1977.

Walling, D. E. and Quine, T. A.: Calibration of caesium?137 measurements to provide quantitative erosion rate data, Land Degrad. Develop., 2, 161-175, 1990. 
Williams, J. R. and Berndt, H. D.: Sediment yield prediction based on watershed hydrology, Trans. Am. Soc. Agr. Eng., 20, 11001104, 1977

Wischmeier, W. H. and Smith, D. D.: Predicting rainfall-erosion losses from cropland east of the Rocky Mountains. Agriculture Handbook, 282 pp., USDA-ARS, 1965.

Young, R. A., Onstad, C., Bosch, D., and Anderson, W. P.: AGNPS: A nonpoint-source pollution model for evaluating agricultural watersheds, J. Soil Water Conserv., 44, 168-173, 1989.

Yu, B., Rose, C. W., Ciesiolka, C. A., Coughlan, K. J., and Fentie, B.: Toward a framework for Runoff and soil loss prediction using GUEST technology, Aust. J. Soil Res., 35, 1191-1212, 1997.
Zegeye, A. D., Steenhuis, T. S., Blake, R. W., Kidnau, S., Collick, A. S., and Dadgari, F.: Assessment of Upland Erosion Processes and Farmer Perception of Land conservation in Debre Mawi Watershed, near Lake Tana, Ethiopia, Ecohydrol. Hydrobiol., 10, 297-306, 2010.

Zumr, D., Dostal, T., and Devaty, J.: Identification of prevailing storm runoff generation mechanisms in an intensively cultivated catchment, J. Hydrol. Hydromech., 63, 246-254, 2015. 